\title{
Being an Involved Father: What Does It Mean?1
}

\section{Garret D. Evans and Kate Fogarty ${ }^{2}$ \\ Overview}

It seems that more and more folks are sharing the message that fathers should be more involved in caring for their children. You may hear this message on $\mathrm{TV}$, on the radio, where you worship, at school, at meetings, at work, and, especially, at home. Father involvement is defined as, men's "positive, wide-ranging, and active participation in their children's lives" (Marsiglio et al., 2000, p. 276).

\section{How Much Is Enough?}

Efforts to get every father more involved in their children's lives leaves many fathers asking themselves: "How much is enough? When have I done enough to be considered an 'involved' father?"

Many of us remember how much or how little involved our fathers were in raising us. We notice the difference in today's dads. More fathers are involved in caring for their children than their own fathers were, especially in the early phases of a childs life (Manlove \& Vernon-Feagans, 2002). You may end up asking yourself if it's enough just to do more than your father did. Perhaps you coach a little league team or shuttle your child back and forth to games.
Maybe you cook dinner for your child or, as a new father, feed your baby or change diapers. You may even take the time for a sit-down talk about sexuality with your child. You may find yourself asking the question, "How much time and attention do I need to give my child to ensure she or he grows up healthy?"

Instead of counting how many minutes you spend with your child as a measure of "good" fathering, ask yourself, "What do I do with my child with the time that I have?" Researchers generally find the quality and type of activities that you do with your child are far more important than the amount of time you spend with them (Palkovitz, 2002).

Here is a list of strategies that you can use to make sure that you have a healthy and "involved" relationship with your child.

\section{Spend Quality Time with Your Child}

Quality time is an expression used a lot on TV and in books and magazines about parenting. The trouble is, many people aren't really sure what quality time is. In essence, quality time is time that parents use to focus on healthy, positive, and nurturing experiences with their child. The emphasis is on what

1. This document is FCS2141, one of a series of the Family, Youth, and Community Sciences Department, Florida Cooperative Extension Service, Institute of Food and Agricultural Sciences, University of Florida. Publication: December 1999. Revised: July 2005. Please visit the EDIS Web site at http://edis.ifas.ufl.edu

2. Garret D. Evans, Psy.D., former assistant professor in Clinical Psychology, and Kate Fogarty, Ph.D., assistant professor, Youth Development, both of the Department of Family, Youth and Community Sciences, Florida Cooperative Extension Service, Institute of Food and Agricultural Sciences, University of Florida, Gainesville FL 32611.

The Institute of Food and Agricultural Sciences (IFAS) is an Equal Opportunity Institution authorized to provide research, educational information and other services only to individuals and institutions that function with non-discrimination with respect to race, creed, color, religion, age, disability, sex, sexual orientation, marital status, national origin, political opinions or affiliations. U.S. Department of Agriculture, Cooperative Extension Service, University of Florida, IFAS, Florida A. \& M. University Cooperative Extension Program, and Boards of County Commissioners Cooperating. Larry Arrington, Dean 
you do with your child instead of how much time you spend with them. Here are a few rules of thumb you can use to decide whether you are spending quality time with your child:

- Is your child the center of your attention-or are you just trying to keep them busy while you do other things?

- During your time together, are you involved in activities that both you and your child enjoy?

- Are you investing time and energy in your children's lives on a daily basis or are you interacting with them just when it is convenient?

- Are you happy just spending ordinary time with your child with no particular purpose or goal in mind?

If you answered "yes" to all these questions, it looks like you are spending quality time with your child. It's important for fathers to spend quality time because, in most families, they are not the child's primary caregiver. This means that others (such as child care workers, teachers, and mothers) spend more time with your child each week than you do.

Quality, positive interactions help form a healthy bond between fathers and their children. These interactions help father-child attachment to grow. Fathers can understand their child's world a little better and children will be able to see and understand their dad as a real person.

\section{Stay Involved in All Phases of Their Life}

Being involved in all aspects of parenting is important part of being an involved father. Some fathers are more comfortable with teaching, playing with, or even disciplining their child because they see these activities as what a father is supposed to do. However, research clearly shows that fathers who are involved in all phases of their child's care are happier as a parent and have healthier, more successful children.

For many dads, being involved in such a broad range of activities takes a serious commitment. It means being willing to feed and diaper as well as play and problem-solve. Being an involved father means packing a lunch box or attending a parent-teacher conference as well as cleaning a bicycle and going shopping. It means being willing to share in all parts of your child's life.

Doing more care-taking activities (e.g., diapering, dressing, bathing, etc.) seems a little unnatural for some fathers, at least at first. When they do it a little more, dads almost always find that it's worthwhile-they see these actions improving their relationship with their child.

\section{Don't Confuse Providing with Loving}

Men may get caught up with the idea that providing for children is the best way to care for and express love for them. While it's true that creating the means for food, clothes, and shelter is a great way to provide for a child - it's not the only way to show caring. In fact, these basics are just the beginning.

There is a maxim, "I've never seen a tombstone that read, I wish I'd spent more time at work." The message is that, as we grow older, most of us wish we would have spent more time with our families and less time trying to get ahead at work. In the same way, you probably have never heard a child say, "I wish my dad spent more time at work."

More than anything in the world, children want their parents' attention and love. Further, research shows that children who receive positive attention from their parents do better in most all aspects of their lives (home, school, work, etc.) than children who do not receive this attention. This is regardless of how much money they have or the type of neighborhood they live in. So remember, being a good father doesn't mean making sure your child has all the best toys, or lives in the best neighborhood. It means making sure your child has all the benefits of having you in their life.

\section{Have a Plan (Where to Start)}

Where to start? You probably have many demands on your time including, commitments to your spouse, your job, your friends, and yourself. You may wonder what you are going to stop or drop to spend more quality time with your child. No one has said that being an involved father is easy-its not. It's 
especially hard for new fathers who suddenly find that they have to make a lot of room in their life for a baby's absolute demand for attention.

A good motivator and helper for beginning fathers are guides on fathering and books that help dispel myths about fatherhood and masculinity. Some suggested books and guides on fatherhood are listed in the reference section. These resources help fathers to better understand the role they play in their family and in their children's lives.

New and experienced fathers alike can start with a small plan. Set aside a block of time for one type of activity that you are going to do with your child. If your child is older, pick something you have hardly ever done before. Maybe you will decide to play with them for 15 minutes before dinner, or help them with their homework. You might decide to be a regular part of bath time or make a snack for them between meals. Commit yourself to this small activity. You may even find that you enjoy it. This time alone with your child will grow and become more rewarding for both of you. After you take this small step, it becomes easier to do other things with your child.

Don't wait to be asked, volunteer and take responsibility; talk it over with the other parent and agree on a plan. If you are a new father, view your caretaking role as a partnership with your spouse or partner rather than as a "helper" or "assistant." Research shows that a father's care of his infants includes soothing, bedtime activities, diapering, and feeding and that most new fathers engage in at least one of these activities on a given weekday (Manlove \& Vernon-Feagans, 2002). Your sharing of parental responsibilities is beneficial, considering that in most families both parents need to earn income to survive economically. Most important, fathering your child, regardless of whether your child is a girl or boy, contributes to her or his positive development.

Realize that, as you become more involved in your child's life, you may become less involved in other areas of your life. You may not be able to work as many overtime shifts or stay as late at work. You may have to say no to an outing or two with the guys, take a season off from your bowling or soccer league. Know that in the end, most fathers agree that the benefits that they receive through building their relationship with their child far outweigh these sacrifices. Last, these benefits influence the development of your child into a successful adult and future parent.

\section{Recommended Resources}

Boyhood. Growing up male: A multicultural anthology. (1998). F. Abbot \& M. Kimmel (Editors).

Real boys: Rescuing our sons from the myths of boyhood. (1999). W. Pollack.

The Fathers Almanac: From Pregnancy to Preschool, Baby Care to Behavior: The Complete and Indispensable Book of Practical Advice and Ideas for Every Man Discovering the Fun and Challenge of Fatherhood. (1992). S. Adams Sullivan.

The New Father Book: What Every Man Needs to Know to be a Good Dad. (1998). W. Horn \& A. Feinstein

Wisdom of Our Fathers: Inspiring Life Lessons from Men Who Have Had Time to Learn Them. (1999). J. Kita

\section{References}

Biller, H. (1993). Fathers and Families: Paternal Factors in Child Development. Westport, CT: Auburn House/Greenwood Publishing Group.

Bonney, J.F., Kelley, M.L., \& Levant, R.F. (1999). A model of fathers behavioral involvement in child care in dual-earner families. Journal of Family Psychology, 13, 401-415.

Colorado Foundation for Families and Children. (2002). Colorado fathers resource guide. Denver, CO: Colorado Fatherhood Connection.

Kazura, K. (2000). Fathers qualitative and quantitative involvement: An investigation of attachment, play, and social interactions. The Journal of Mens Studies, 9, 41-57. 
Manlove, E.E. \& Vernon-Feagans, L. (2002).

Caring for infant daughters and sons in dual-earner households: Maternal reports of father involvement in weekday time and tasks. Infant \& Child

Development, 11, 305-320.

Marsiglio, W., Day, R.D., \& Lamb, M.E. (2000). Exploring fatherhood diversity: Implications for conceptualizing father involvement. Marriage and Family Review, 29, 269-293.

McBride, B.A., Schoppe-Sullivan, S.J., \& Ho, M.H. (2005). The mediating role of fathers school involvement on student achievement. Applied Developmental Psychology, 26, 201-216.

Palkovitz, R. (2002). Involved fathering and child development: Advancing our understanding of good fathering. In C.S. Tamis-LeMonda \& N.

Cabrera (Eds.), Handbook of father involvement: Multidisciplinary perspectives. Mahwah, NJ:

Lawrence Erlbaum (pp. 119-140). 